\title{
SOX GENES: ARCHITECTS OF DEVELOPMENT
}

\author{
Heather M. Prior and Michael A. Walter \\ Ocular Genetics Research Group, University of Alberta, \\ Edmonton, Alberta, Canada
}

Development in higher organisms involves complex genetic regulation at the molecular level. The emerging picture of development control includes several families of master regulatory genes which can affect the expression of downstream target genes in developmental cascade pathways. One new family of such development regulators is the SOX gene family. The SOX genes are named for a shared motif called the $\underline{S} R Y$ box, a region homologous to the DNA-binding domain of SRY, the mammalian sex determining gene. Like SRY, SOX genes play important roles in chordate development. At least a dozen human SOX genes have been identified and partially characterized (Tables 1 and 2). $\mathrm{Mu}$ tations in SOX9 have recently been linked to campomelic dysplasia and autosomal sex reversal, and other SOX genes may also be associated with human disease.

\section{OVERVIEW: DEVELOPMENT CONTROL BY ARCHITECTURAL TRANSCRIPTION FACTORS}

The process of development includes the increasing differentiation of pluripotent progenitor cells. Since the pattern of transcribed proteins within each cell ultimately determines its identity in the context of tissue, organ, and organism, the regulation of transcription is at the foundation of any development control pathway.

Basic gene transcription is regulated by transcription factors, proteins which bind specific DNA sequences called promoters or enhancers located within and around the gene $(1,2)$. In addition to a DNA-binding domain, most tran-

Address correspondence and reprint requests to: Michael A. Walter, Ocular Genetics Laboratory, 671 Heritage Medical Research Center, University of Alberta, Edmonton, Alberta, T6G 2S2, Canada. scription factors have a distinct activation domain which interacts with other proteins to coordinately control gene transcription. A simplified model of the regulation of downstream target genes by transcription factors is shown in Fig. 1.

Large "families" of transcription factors which are involved in the control of developmental pathways have been identified. These gene families encode proteins characterized by well-defined DNA-binding motifs, such as zincfingers or homeobox domains, typically highly conserved across species $(3,4)$. Many of these genes were first studied in Drosophila. An example is the HOM/HOX (homeobox-containing) gene complexes which play a role in early pattern formation in the Drosophila larva and have also been implicated in pattern formation in early vertebrate development (5). Within the PAX (paired box) family of genes (6), PAX6 is a master eye development control gene in organisms as diverse as insects, cephalopods, and humans. Interestingly, mutations in this gene cause either aniridia or autosomal dominant keratitis, two congenital eye defects in humans (7-9). Mutations in other PAX genes also cause human diseases, including coloboma and renal anomalies (PAX2), and Waardenburg syndrome (PAX3) $(10,11)$. While SOX genes have not yet been as well characterized, they appear to also play important roles in early development and to have interesting associations to human disease.

The SOX genes belong to a large group of genes in which the DNA-binding domain is called a high mobility group (HMG) box (12). Two basic types of HMG-class proteins can be delineated. One group is characterized by proteins containing multiple HMG boxes, having a general affinity for binding DNA independent of its sequence. This group includes the HMG-1 protein, ubiquitous binding factor (UBF), and mitochondrial transcription factor 1 (MT-TF1). The second category of HMG-class proteins consists of those with a single HMG box and that bind DNA in a highly sequence-specific manner. 
TABLE 1. Accession numbers of human and mouse Sox sequences

\begin{tabular}{lll}
\hline & $\begin{array}{c}\text { Accession } \\
\text { Number }\end{array}$ & $\begin{array}{c}\text { Sequence } \\
\text { Data }\end{array}$ \\
\hline Human Gene & & \\
SRY & L08063 & Complete \\
& L10102 & \\
& L10101 & \\
X53772 & \\
SOX2 & Z31560 & Partial \\
SOX3 & X71135 & Complete \\
SOX4 & X70683 & Complete \\
SOX5 & X65662 & HMG box \\
SOX6 & X65663 & HMG box \\
SOX8 & X65664 & HMG box \\
SOX9 & Z46629 & Complete \\
& S74504-S74506 & \\
SOX10 & X65666 & HMG box \\
SOX11 & X73038 & HMG box \\
SOX12 & X73039 & HMG box \\
Mouse Gene & & \\
Sry & X55491 & Complete \\
Sox1 & X94126 & Complete \\
Sox2 & X94127 & Complete \\
& U31967 & \\
Sox3 & X94125 & Complete \\
Sox4 & X70298 & Complete \\
Sox5 & X65657 & Complete \\
Sox6 & S45834 & \\
Sox7 & U32614 & Complete \\
Sox8 & X65660 & HMG box \\
Sox9 & Z18957 & HMG box \\
Sox10 & Z18958 & HMG box \\
Sox11 & Z18959 & HMG box \\
Sox12 & Z18960 & HMG box \\
Sox13 & Z18961 & HMG box \\
Sox14 & Z18962 & HMG box \\
Sox15 & X70909 & HMG box \\
Sox16 & HMG box \\
Sox17 & HMG box \\
Sox18 & HMG box \\
\hline & Complete \\
& & \\
\hline & & \\
& & \\
& & \\
& &
\end{tabular}

Some members of this group are proteins encoded by the yeast mating type genes matMc and mat-Al, the white cell regulatory genes $\mathrm{T}$ cell factor-1 (TCF-1) and the lymphocyte enhancer factor-1 (LEF-1) $(13,14)$, as well as the SOX and SRY genes. Genes in this category share about $25 \%$ sequence identity over the 79 amino acid HMG box, with little or no similarity outside this box. It has been directly demonstrated for SRY, SOX4, and SOX5 (15-17) that these proteins bind in the minor groove of DNA at the consensus sequence A/T A/T C A A A G. The binding induces a sharp bend of $80^{\circ}$ to $135^{\circ}$ in the DNA template $(18,19)$, which in turn may act to bring different regulatory regions of the target gene into close proximity. As a result, various transcription factors bound to these regions would be able to interact to activate transcription. DNA-binding proteins with this "structural" mode of action have been appropriately called architectural transcription factors (20).

\section{THE SRY GENE AND SEX DETERMINATION}

The first SOX gene to be successfully cloned and characterized was the SRY gene (Fig. 2), and it remains the defining member of the family (22). The critical region on the $\mathrm{Y}$ chromosome was initially established by molecular analysis of the DNA of sex reversed patients, including XX males with portions of the $\mathrm{Y}$ chromosome translocated to one of the $\mathrm{X}$ chromosomes and $\mathrm{XY}$ females with deletions within the $\mathrm{Y}$ chromosome. Although a number of candidate genes initially looked promising, SRY was shown in 1990 to be the one necessary for male sex determination since mutations within its open reading frame were found in $\mathrm{XY}$ sex reversed patients $(23,24)$. All the mutations identified fell within the HMG box region of the SRY gene. Subsequent experiments showing that $\mathrm{XX}$ transgenic mice carrying the SRY gene were phenotypically male (25) demonstrated that this gene was sufficient for male sex determination.

In male mice, the SRY protein is expressed in the bipotential genital ridge of the developing embryo (26). Outside the genital ridge, SRY mRNA levels are regulated by an unusual translational control system whereby a unique splicing event produces non-functional circular transcripts (27). The gonad in the absence of SRY develops, by default, as an ovary. During male development, SRY acts to induce MIS (Müllerian inhibiting substance) expression, which in turn causes regression of the Müllerian duct system (female), progression of the Wolffian ducts 
TABLE 2. SOX genes

\begin{tabular}{|c|c|c|c|c|c|}
\hline Group & Gene & $\begin{array}{c}\text { Chromosome } \\
\text { (Human) }\end{array}$ & $\begin{array}{c}\text { Sequence } \\
\text { Data } \\
\text { (Human) }^{a}\end{array}$ & $\begin{array}{c}\text { Disease } \\
\text { Association }\end{array}$ & Tissue \\
\hline A & SRY & $\mathrm{Y}$ & + & $X Y$ sex reversal & Genital ridge \\
\hline \multirow[t]{6}{*}{$\mathrm{B}$} & SOXl & & & & \\
\hline & SOX2 & $3 q 26.3-27$ & + & & Embryo CNS \\
\hline & SOX3 & $\mathrm{Xq} 26.2-27.2$ & + & Borjeson-Forssman-Lehmann (?) & Embryo CNS \\
\hline & SOX14 & & & & \\
\hline & SOX15 & & & & \\
\hline & SOX19 & & & & \\
\hline \multirow[t]{4}{*}{$\mathrm{C}$} & SOX4 & $6 p$ & + & & Lymphocytes \\
\hline & SOX11 & & + & & Embryo CNS \\
\hline & SOX12 & & + & & \\
\hline & SOX20 & $17 \mathrm{pl} 3$ & + & & \\
\hline \multirow[t]{3}{*}{$\mathrm{D}$} & SOX5 & & + & & Adult testis \\
\hline & SOX6 & & + & & Testis, embryo CNS \\
\hline & SOX13 & & & & \\
\hline \multirow[t]{3}{*}{$\mathrm{E}$} & SOX8 & & + & & \\
\hline & SOX9 & $17 q 24$ & + & Campomelic dysplasia, sex reversal & Adult testis \\
\hline & SOX10 & & + & & \\
\hline \multirow[t]{3}{*}{$\mathrm{F}$} & SOX7 & & & & \\
\hline & SOX17 & & & & \\
\hline & SOX18 & & & & Muscle \\
\hline
\end{tabular}

${ }^{a}$ Complete human cDNA sequence data for SRY, SOX3, SOX4, and SOX9 only.

(male), and gonadal development as testis (28). The SRY product may also act to induce male steroidogenesis, which in turn leads to male external genitalia. Affinity studies to determine the precise downstream targets of SRY have shown that it probably binds to intervening intermediate factors in both the MIS and the male steroidogenesis pathways (28).

\section{SOX GENES}

The SOX (SRY-related HMG box) genes were initially identified through their homology to the HMG box of SRY. By definition, the DNA-binding domain of SOX genes is at least $60 \%$ similar or $50 \%$ identical to the 79 amino acid HMG box of the SRY gene. At least 19 SOX genes have been identified and divided into six groups, designated A-F (Table 2), according to the similarities of their HMG box regions (Fig. 3). SOX genes have been found in Drosophila and many verte- brates, including mouse, chicken, gull, frog, turtle, zebrafish, marsupials, and humans (12,29-35).

Although the majority of work has concentrated on the mouse Sox genes, several human

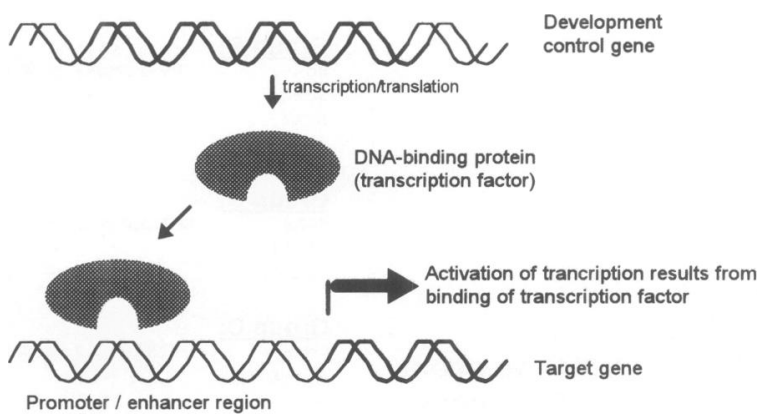

FIG. 1. Downstream regulation model Development control genes encode transcription factors with DNA-binding domains. These factors bind to the promoter/enhancer regions of target genes and often interact with other proteins to influence transcription levels in the target genes. 


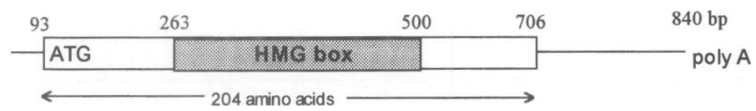

FIG. 2. Structure of the SRY gene

The SRY gene has a single open reading frame which contains a 79-amino acid HMG box (21).

genes have also been partially characterized. Apart from SRY located on the Y chromosome and SOX 3 on the $\mathrm{X}$ chromosome, other human SOX genes are autosomal and those whose chromosomal location is known are scattered throughout the genome. Although SOX genes appear to be predominantly expressed in the developing testis and nervous system, additional studies are needed to determine whether this expression pattern has functional or evolutionary significance. Several SOX genes, including SRY, SOX3, and SOX4 (36-39), are single exon genes; SOX9, however, contains three exons $(40,41)$. Full cDNA sequences have been reported for human SRY, SOX3, SOX4, and SOX9, and for mouse Sry, Sox1, Sox2, Sox3, Sox4, Sox6, and Sox 18. Additional sequence data are primarily confined to the HMG box region (Table 2).

SRY is the sole member in its group (A) and is most similar to the group $B$ genes. The best studied members of group B appear to function as architects of neuronal development. Soxl, Sox 2 , and Sox 3 are expressed at high levels in the murine embryonic nervous system (42) and chicken Sox 2 and Sox 3 are expressed in the undifferentiated cells of the neural epithelium (34). Sox 2 is expressed in developing eye tissues and a recent study implicates chicken Sox 2 in the lensspecific regulation of the $\delta 1$-crystallin gene (43). Human SOX2 has been partially cloned and mapped to chromosome 3q26.3-27 (44). In addition, murine Sox 2 has been found to complex with another transcription factor, Oct-3, to promote transcriptional activation of fibroblast growth factor 4 (FGF-4) in embryonic carcinoma cell lines (45). This type of complex transactivation represents an intriguing mechanism in developmental regulation.

SOX3 has the highest similarity to the HMG box of SRY, and recent work has suggested that SRY may have in fact originated as a homologue of the Sox 3 gene $(37,42)$. Since other genes on the $\mathrm{Y}$ chromosome are also similar to genes on the $\mathrm{X}$ chromosome, it suggests that the sex chromosomes may have originally been a homologous pair like the autosomes (46). In humans, SOX 3 shows widespread expression in fetal tissues, including brain and spinal cord, as well as in some adult tissues (37). A patient with a deletion including the SOX3 gene has hemophilia and mental retardation. Although this patient has small testes, his male phenotype suggests that SOX3 is not necessary for testis formation. This gene is, however, a candidate for the Borjeson-Forssman-Lehmann syndrome, an X-linked condition which includes mental retardation, epilepsy, and hypogonadism, and which maps to the same region of Xq26-27 as the SOX3 gene (37).

In group C, Sox 4 has been characterized more extensively than SOX20, Sox 12 , or Sox 11 $(47,48)$, although Sox 11 has been shown to have neuronal specific expression patterns in chicken (34). Sox4 is expressed in T cells and pre-B lym-
FIG. 3. HMG box comparison of SOX genes by group

Amino acid sequnces are given for the HMG boxes of human (SOX) and mouse (Sox) genes. Amino acid identities are indicated by dashes.

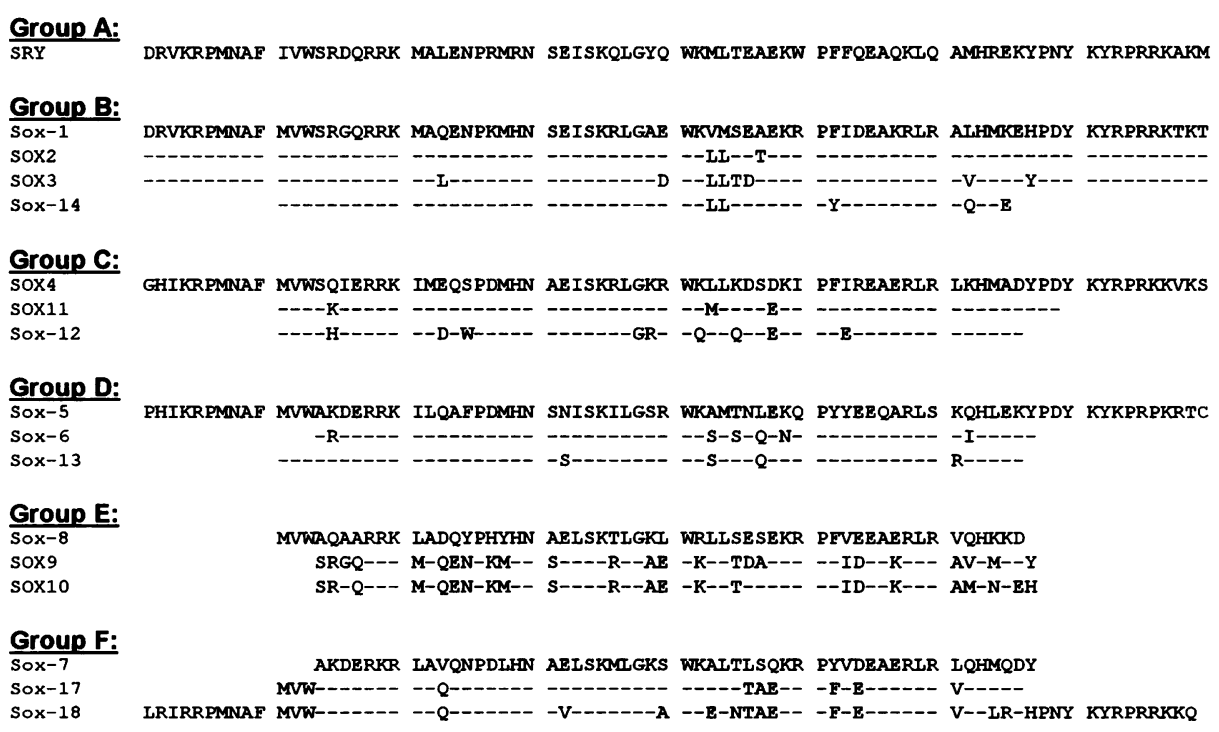


phocytes and is involved, together with TCF-1 and LEF-1, in controlling lymphocyte differentiation. Binding studies have shown that the Sox 4 protein has an affinity for the DNA sequence AACAAAG, a motif found in the enhancer region of some $\mathrm{T}$ cell receptor genes. Sox 4 also contains a serine-rich transactivation domain (separable from its DNA-binding domain), and thus it represents the first SOX gene to have the characteristic structure of a classical transactivator of transcription (49).

In group D, Sox 5 and Sox6 are both expressed in adult mouse testis. Sox 5 is exclusively expressed in post-meiotic round spermatids and may play a role in spermatogenesis (50). The DNA-binding domains of both Sox 5 and Sox6 have affinity for the sequence AACAAT, and binding by Sox 5 induces a sharp bend in the template DNA. Sox6 is also expressed in segments of the developing anterior nervous system, suggesting a possible role in CNS differentiation and growth, in addition to its proposed role in testis determination (51).

The best-characterized human SOX gene is SOX9, a member of the group E subclass. Mutations in this gene cause campomelic dysplasia (CPMDl) and autosomal sex reversal (SRAl) $(40,41)$. CPMD 1 is a rare congenital skeletal malformation syndrome characterized by bowing of the long bones and defects in cartilage formation. It is associated with autosomal sex reversal, and two-thirds of XY CPMDl patients develop with female or ambiguous genitalia $(52,53)$. The syndrome was localized to the distal portion of chromosome $17 \mathrm{q}$ by analysis of DNA from patients with chromosome translocations in this region (54). SOX9 was investigated as a candidate gene for this disease since the mouse Sox 9 mapped to the homologous region and had been shown to have a primary role in skeletal formation $(55,56)$. Mutations in SOX9 were detected in two-thirds of CPMDl patients without chromosomal translocations, suggesting that the gene was involved in the disease phenotype; intriguingly, however, several CPMDl translocation breakpoints mapped just outside of the SOX9 gene $(40,41)$. The SOX9 gene codes for a protein with an HMG box DNA-binding domain and a putative activation domain containing proline and glutamine residues. The mutations in CPMDl patients are predicted to result in loss of function alleles and an autosomal dominant mode of inheritance for the disease due to haploinsufficiency. Dosage sensitivity often plays a role in sex determination mechanisms, and fur- ther studies of SOX9 may indeed extend the current understanding into this area.

In group $\mathrm{F}$, preliminary analyses have been carried out on the Sox 17 and Sox 18 genes in the mouse. The Sox 18 protein, like Sox 4 , has a serine-rich region as a putative transactivation domain in addition to its HMG box. Sox 18 expression is limited to smooth and striated muscle in the adult mouse (57).

\section{FUTURE DIRECTIONS}

Research into SOX genes is still in its preliminary stages. Most studies to date have focussed on isolating and sequencing various members of the family, along with studies of gene expression and DNA-binding affinities. This work has shown that members of the SOX gene family may be involved in many different aspects of development, including sex determination, testis formation, neuronal development, lymphocyte differentiation, and chondrogenesis.

Future investigations will focus on determining the molecular targets of SOX proteins in order to elucidate their mode of action more precisely. As human SOX genes are cloned, they will become positional candidates for various diseases and mutation analyses will help to correlate structural domains with function. Because SOX genes have been found in diverse organisms, model systems for studying human mutation and disease may be developed in other species. A very promising area that has just begun to be explored concerns the interactions of SOX proteins with one another and with other development control factors. Various SOX genes are thought to interact, including SRY with SOX9 and Sox 5 with Sox6. Additional interactions, including Sox6 with members of the Hox gene family, chicken Sox11 with members of the Achaete-scute complex, and Sox 2 with Oct-3, have also been suggested $(28,37,42)$. These associations may allow for structurally complex DNA-binding and transactivation mechanisms, producing highly specified control of developmental pathways.

\section{ACKNOWLEDGMENTS}

We thank Kristin Hickey, Dr. Ian MacDonald, and Dr. Rachel Wevrick for their helpful comments, and acknowledge the support of the RP 
Foundation-Fighting Blindness and the Alberta Heritage Foundation for Medical Research.

\section{REFERENCES}

1. Mitchell P, Tjian R. (1989) Transcription regulation in mammalian cells by sequencespecific DNA binding proteins. Science 245: 371-378.

2. Tjian R, Maniatis T. (1994) Transcriptional activation: A complex puzzle with few easy pieces. Cell 77: 5-8.

3. Busch SJ, Sassone CP. (1990) Dimers, leucine zippers and DNA-binding domains. Trends Genet. 6: 36-40.

4. Struhl K. (1990) Helix-turn-helix, zinc-finger, and leucine-zipper motifs for eukaryotic transcriptional regulatory proteins. Trends Biochem. 14: 137-140.

5. Krumlauf R. (1994) Hox genes in vertebrate development. Cell 78: 191-201.

6. Hill RE, Hanson IM. (1992) Molecular genetics of the Pax gene family. Curr. Opin. Cell Biol. 4: 967-972.

7. Jordan T, Hanson I, Zaletayev D, et al. (1992) The human PAX6 gene is mutated in two patients with aniridia. Nat. Genet. 1: 328-332.

8. Halder G, Callaerts P, Gehring W. (1995) New perspectives on eye evolution. Curr. Opin. Genet. Dev. 5: 602-609.

9. Mirzayans F, Pearce WG, MacDonald IM, Walter M. (1995) Mutation of the PAX6 gene in patients with autosomal dominant keratitis. Am. J. Hum. Genet. 57: 539-548.

10. Tassabehji $M$, Read AP, Newton $V$, et al. (1992) Waardenburg's syndrome patients have mutations in the human homologue of the Pax-3 paired box gene. Nature 355: 635636.

11. Sanyanusin P, Schimmenti LA, McNoe LA, et al. (1995) Mutation of the PAX2 gene in a family with optic nerve colobomas, renal anomalies and vesicoureteral reflux. Nat. Genet. 9: 358-363.

12. Laudet V, Stehelin D, Clevers H. (1993) Ancestry and diversity of the HMG box superfamily. Nucleic Acids Res. 21: 2493-2501.

13. Waterman M, Jones K. (1990) Purification of TCF- $1 \alpha$, a T-cell-specific transcription factor that activiates the T-cell receptor $c \alpha$ gene ehancer in a context-dependent manner. New Biol. 2: 621-636.

14. Travis A, Amsterdam A, Belanger C, Gross- chedl R. (1991) LEF-1, a gene encoding a lymphoid-specific protein with an HMG domain, regulates $\mathrm{T}$-cell receptor $\alpha$ enhancer function. Gene. Dev. 5: 880-894.

15. van de Wetering $M$, Clevers H. (1992) Sequence-specific interaction of the HMG box proteins TCF-1 and SRY occurs within the minor groove of a Watson-Crick double helix. $E M B O$ J. 11: 3039-3044.

16. Connor F, Cary PD, Read CM, et al. (1994) DNA binding and bending properties of the post-meiotically expressed Sry-related protein Sox-5. Nucleic Acids Res. 22: 3339-3346.

17. Harley VR, Lovell-Badge R, Goodfellow PN. (1994) Definition of a consensus DNA-binding site for SRY. Nucleic Acids Res. 22: 15001501.

18. Ferrari S, Harley VR, Pontigiggia A, Goodfellow PN, Lovell-Badge R, Bianchi ME. (1992) SRY, like HMG 1, recognizes sharp angles in DNA. EMBO J. 11: 4497-4506.

19. Giese K, Cox J, Grosschedl R. (1992) The HMG domain of lymphoid enhancer factor 1 bends DNA and facilitates assembly of functional nucleoprotein structures. Cell 69: $1-20$.

20. Grosschedl R, Giese K, Pagel J. (1994) HMG domain proteins: Architectural elements in the assembely of nucleoprotein structures. Trends Genet. 10: 94-100.

21. Clépet C, Schafer AJ, Sinclair AH, Palmer MS, Lovell-Badge R, Goodfellow PN. (1993) The human SRY transcript. Hum. Mol. Genet. 2: 2007-2012.

22. Gubbay J, Collignon J, Koopman P, et al. (1990) A gene mapping to the sex-determining region of the mouse $\mathrm{Y}$ chromosome is a member of a novel family of embryonically expressed genes. Nature 346: 245-250.

23. Sinclair A, Berta P, Palmer MS, et al. (1990) A gene from the human sex-determining region encodes a protein with homology to a conserved DNA-binding motif. Nature 346: 240-244.

24. Berta P, Hawkins JR, Sinclair A, Taylor A Griffiths BL, Goodfellow PN, Fellous $M$. (1990) Genetic evidence equating SRY and the male sex determining gene. Nature 348: 248-250.

25. Koopman P, Gubbay J, Vivian N, Goodfellow P, Lovell-Badge R. (1991) Male development of chromosomally female mice transgenic for SRY. Nature 351: 117-121.

26. Hacker A, Capel B, Goodfellow PN, LovellBadge R. (1995) Expression of Sry, the 
mouse sex determining gene. Development 121: 1603-1614.

27. Capel B, Swain A, Nicolis S, Hacker A, Walter MA, Koopman P, Goodfellow PN, Lovell-Badge R. (1993) Circular transcripts of the testis-determining geneSry in adult mouse testis. Cell 73: 1019-1030.

28. Haqq CM, King CY, Ukiyama E, et al. (1994) Molecular basis of mammalian sexual determination: Activation of Müllerian Inhibiting Substance gene expression by SRY. Science 266: 1494-1500.

29. Coriat AM, Muller U, Harry JL, Uwanogho D, Sharpe PT. (1993) PCR Amplification of Sry-related sequences reveals evolutionary conservation of the SRY-box motif. PCR Methods Appl. 2: 218-222.

30. Chardard D, Chesnel A, Gozé C, Doumon C, Berta P. (1993) Pw Sox-1: The first member of the Sox gene family in Urodeles. Nucleic Acids Res. 21: 3576.

31. Denny P, Swift S, Brand N, Dabhade N, Barton P, Ashworth A. (1992) A conserved family of genes related to the testis determining gene, SRY. Nucleic Acids Res. 20: 2887.

32. Foster JW, Graves JA. (1994) An SRY-related sequence on the marsupial $\mathrm{X}$ chromosome: Implications for the evolution of the mammalian testis determining gene. Proc. Natl. Acad. Sci. U.S.A. 91: 1927-1931.

33. Griffiths R. (1991) The isolation of conserved DNA sequences related to the human sexdetermining region $\mathrm{Y}$ gene from the lesser black-backed gull (Larus fuscus). Proc. R. Soc. Lond. B Biol. Sci. 244: 123-128.

34. Uwanogho D, Rex M, Cartwright EJ, et al. (1995) Embryonic expression of the chicken Sox2, Sox3, and Soxll genes suggests an interactive role in neuronal development. Mech. Dev. 49: 23-36.

35. Vriz S, Lovell-Badge R. (1995) The zebrafish Zf-Sox 19 protein: A novel member of the Sox family which reveals highly conserved motifs outside of the DNA-binding domain. Gene 153: 275-276.

36. Behlke MA, Bogan JS, Beer-Romero P, Page DC. (1993) Evidence that the SRY protein is encoded by a single exon on the human $\mathrm{Y}$ chromosome. Genomics 17: 736-739.

37. Stevanovic $M$, Lovell-Badge R, Collignon J, Goodfellow P. (1993) SOX3 is an X-linked gene related to SRY. Hum. Mol. Genet. 2: 2013-2018.

38. Farr CJ, Easty DJ, Ragoussis J, Collignon J, Lovell-Badge R, Goodfellow PN. (1993)
Characterization and mapping of the human SOX4 gene. Mamm. Genome 4: 577-584.

39. Schilham MW, Vaneijk M, Vandewetering M, Clevers HC. (1993) The murine Sox-4 protein is encoded on a single exon. Nucleic Acids Res. 21: 2009.

40. Foster JW, Dominguez-Steglich MA, Guioli $S$, et al. (1994) Campomelic dysplasia and autosomal sex reversal caused by mutations in an SRY-related gene. Nature 372: 525530.

41. Wagner $\mathrm{T}$, Wirth $\mathrm{J}$, Meyer J, et al. (1994) Autosomal sex reversal and campomelic dysplasia are caused by mutations in and around the SRY-related gene SOX9. Cell 79: 1111-1120.

42. Collignon J, Shanthini S, Hacker A, et al. (1996) A comparison of the properties of Sox-3 with Sry and two related genes, Sox-1 and Sox-2. Development 122: 509-520.

43. Kamachi Y, Sockanathan S, Liu Q, Breitman M, Lovell-Badge R, Kondoh H. (1995) Involvement of SOX proteins in lens-specific activation of crystallin genes. $E M B O \mathrm{~J}$. 14: 3510-3519.

44. Stevanovic $M$, Zuffardi $O$, Collignon $J$, Lovell-Badge R, Goodfellow P. (1994) The cDNA sequence and chromosomal location of the human SOX2 gene. Mamm. Genome 5: 640-642.

45. Yuan H, Corbi N, Basilico C, Dailey L. (1995) Developmental-specific activity of the FGF-4 enhancer requires the synergistic action of Sox2 and Oct-3. Gene. Dev. 9: 2635-2645.

46. Ohno S. (1967) Sex Chromosomes and SexLinked Genes. Springer, Berlin.

47. Goze C, Poulat F, Berta P. (1993) Partial cloning of SOX-11 and SOX-12, two new human SOX genes. Nucleic Acids Res. 21: 2943.

48. Meyer J, Wirth J, Held M, Schempp W, Scherer G. (1996) SOX20, a new member of the SOX gene family, is located on chromosome 17pl3. Cytogenet. Cell Genet. 72: 246249.

49. van de Wetering $M$, Oosterwegel $M$, van Norren K, Clevers H. (1993) Sox-4, a Srylike HMG protein, is a transcriptional activator in lymphocytes. EMBO J. 12: 3847-3854.

50. Denny P, Swift S, Connor F, Ashworth A. (1992) An SRY-related gene expressed during spermatogenesis in the mouse encodes a sequence-specific DNA-binding protein. EMBO J. 11: 3705-3712.

51. Connor F, Wright E, Denny P, Koopman P, 
Ashworth A. (1995) The Sry-related HMG box-containing gene Sox6 is expressed in the adult testis and developing nervous system of the mouse. Nucleic Acids Res. 23: 33653372 .

52. Houston CS, Opitz JM, Spranger JW, et al. (1983) The campomelic syndrome: review, report of 17 cases, and follow-up on the currently 17-year old boy first reported by Marteaux et al. in 1971. Am. J. Med. Genet. 15: 3-28.

53. McKusick VA. (1992) Mendelian Inheritance in Man. The Johns Hopkins Press, Baltimore, pp. 1262-1263.

54. Tommerup N, Schempp W, Meinecke P, et al. (1993) Assignment of an autosomal sex reversal locus (SRAl) and campomelic dysplasia (CMPD1) to 17q24.3-25.1. Nat. Gene. 4: $170-174$.

55. Wright EM, Snopek B, Koopman P. (1993) Seven new members of the Sox gene family expressed during mouse development. $\mathrm{Nu}$ cleic Acids Res. 21: 744.

56. Wright E, Hargrave MR, Christiansen J, et al. (1995) The Sry-related gene Sox9 is expressed during chondrogenesis in mouse embryos. Nat. Gene. 9: 15-20.

57. Dunn TL, Mynett-Johnson L, Wright EM, Hosking BM, Koopman PA, Muscat GEO. (1995) Sequence and expression of Sox-18 encoding a new HMG-box transcription factor. Gene 161: 223-225. 